\title{
Predator Insect Families Associated With Melon Crop in a Semiarid Region in Brazil
}

\author{
Adriano Soares de Carvalho ${ }^{1}$, Adrian José Molina-Rugama ${ }^{2}$, Francisco Edivino Lopes Silva ${ }^{2}$, \\ Ewerton Marinho Costa ${ }^{3} \&$ Elton Lucio Araujo ${ }^{2}$ \\ ${ }^{1}$ Instituto Federal de Educação, Ciência e Tecnologia do Rio Grande do Norte, Ipanguaçu, RN, Brazil \\ ${ }^{2}$ Centro de Ciências Agrárias, Universidade Federal Rural do Semi-Árido, Mossoró, RN, Brazil \\ ${ }^{3}$ Centro de Ciências e Tecnologia Agroalimentar, Universidade Federal de Campina Grande, Pombal, PB, Brazil \\ Correspondence: Elton Lucio Araujo, Centro de Ciências Agrárias, Universidade Federal Rural do Semi-Árido, \\ Av. Francisco Mota, 572, Caixa Postal 137, Bairro Costa e Silva, CEP: 59625-900, Mossoró, RN, Brazil. Tel: \\ 55-(84)-994-014-045. E-mail: elton@ufersa.edu.br
}

Received: June 5, $2018 \quad$ Accepted: July 20, $2018 \quad$ Online Published: September 15, 2018

doi:10.5539/jas.v10n10p267 URL: https://doi.org/10.5539/jas.v10n10p267

\begin{abstract}
Knowledge of diversity of natural enemies in agroecosystems is vital for the integrated pest management. However, surveys of beneficial insects (predators and parasitoids) in the melon crop (Cucumis melo L.) in the semiarid region in Brazil are scarce. Thus, the objective of this study was to know the families of predator insects associated with melon crop in a semiarid region in the state of Rio Grande do Norte (RN), one of the main melon producers in Brazil. The survey study was carried out in a commercial melon area, in the municipality of Baraúna (RN). The samples were collected weekly during the cycle of melon, using passive (Pitfall and Moericke traps) and active (sweep net) collection methods. A total of 13 families of predator insects were collected. The families with the highest relative abundances in the passive collection method were Labiduridae (89.53\%) and Formicidae (6.91\%), while in the active collection method were Chrysopidae (59.81\%) and Staphylinidae (20.56\%). These families contain important species of predator which can promote crop pest suppression in melon agricultural systems.
\end{abstract}

Keywords: biodiversity, Cucumis melo, integrated pest management, natural enemies

\section{Introduction}

Melon crop (Cucumis melo L.) is one of the main segments of agribusiness in the Northeast region of Brazil, where the state of Rio Grande do Norte is the largest melon producer (IBGE, 2016). This region is characterized by semiarid climate (high temperatures and reduced rainfall throughout the year) and vegetation of the Caatinga type (xerophilous and deciduous plants) (Prado, 2003). In the Brazilian semiarid region, the melon crop is usually infested by pests such as whitefly Bemisia tabaci (Hemiptera: Aleyrodidae), leafminer Liriomyza sativae (Diptera: Agromyzidae) and melonworm Diaphania nitidalis (Lepidoptera: Pyralidae) (Araujo et al., 2008).

In order to ensure plant health and productive potential of melon, it is essential to use integrated pest management (IPM). However, many melon farmers widely use chemical control as the primary measure of pest suppression and these products are rarely applied as part of IMP. Successful IPM requires a thorough knowledge of the pest insect's biology, their natural enemies, and the crop to allow rational use of a variety of cultivation and control techniques under differing circumstances (Gullan \& Cranston, 2017). In this context is essential to know and conserve the diversity of agents of biological control (predators and parasitoids) present in the agroecosystems (Crowder \& Jabbour, 2014).

Studies on natural enemy diversity around the world in melon relates the presence of several predatory from the orders Coleoptera, Mantodea, Hemiptera, and Odonata (Vinutha, Kotikal, Venkateshalu, Manjunath, \& Patil, 2017). Although, despite the melon economic importance, little is known about the diversity of predatory insect families that occur in melon production areas in the Brazilian semiarid (Araujo et al., 2008). However, research on the watermelon crop [Citrullus lanatus (Thunb.)], in the semiarid region of Rio Grande do Norte, reports the presence of several families of predators from the orders Coleoptera (Staphylinidae, Carabidae and Coccinellidae) (Costa, Araujo, Silva, Nogueira, \& Silva, 2014a), Hymenoptera (Crabronidae, Vespidae and Sphecidae) (Costa, 
Araujo, Fernandes, Silva, \& Sales Júnior, 2016), Diptera (Syrphidae) (Gomes, Costa, Araujo, Sales Júnior, \& Silva, 2012), Hemiptera (Reduviidae) and Dermaptera (Costa, Silva, Araujo, Santos, \& Sales Junior, 2014b). These groups of natural enemies are indispensable in field crops due to positive effect on phytophagous insect's suppression in several agroecosystems (Gullan \& Cranston, 2017).

It is very important to know the natural enemies diversity in agricultural environment. This information can be used to improve the integrated pest management in the crops and serve as the basis for ecological studies. Therefore, the objective of this study was to know the families of predatory insects associated with the melon crop, under Brazilian semiarid conditions.

\section{Materials and Methods}

The study was conducted during the period from vegetative growth (August 2, 2012) until the harvest of the melon fruits (September 17, 2012), in an area (2.5 ha) of commercial production of yellow melon cv. Goldex, planted at a spacing of $1.80 \times 0.30 \mathrm{~m}$ in the municipality of Baraúna $\left(4^{\circ} 59^{\prime} 06.40^{\prime \prime} \mathrm{S}\right.$ and $37^{\circ} 33^{\prime} 13.90^{\prime \prime} \mathrm{W}$, altitude: $\left.94 \mathrm{~m}\right)$, located in a semiarid region of Rio Grande do Norte, Brazil (Figure 1). The study area was surrounded by strips of native vegetation (Caatinga — with xerophilous and deciduous plants) typical of the Caatinga Biome.

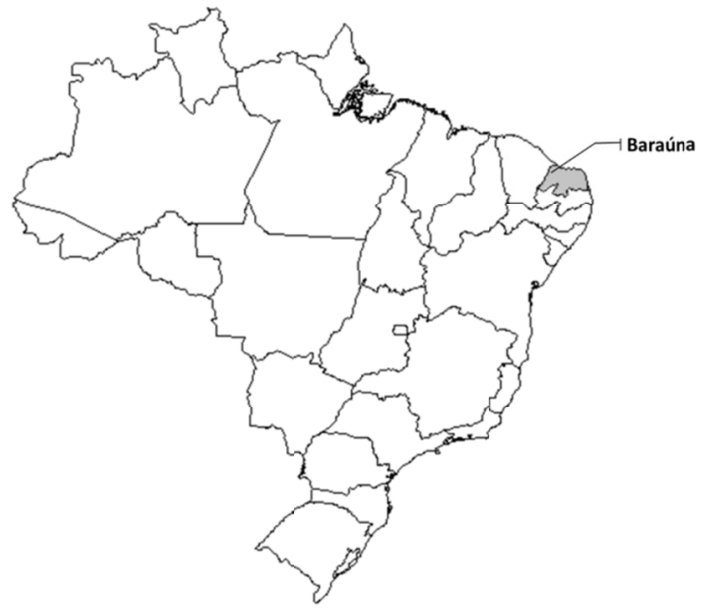

Figure 1. Location of study area, municipality of Baraúna, state of Rio Grande do Norte, Brazil

In the sampled area the cultivation of melon was grown without the use of polyethylene film (mulch) and NWF (Non-Woven Fabric). Agricultural practices such as fertilization, weeding, irrigation and application of insecticides (Deltamethrin 25 CE, Acetamiprid 200 SP, Abamectin 18 CE, Chlorantraniliprole 200 SC, Thiamethoxan $250 \mathrm{WG}$ and Lambda-Cyhalothrin $50 \mathrm{CS}$ ) for pest control were applied. During the study there were no rainfall in the region and the monthly averages of temperature $\left({ }^{\circ} \mathrm{C}\right)$ and relative humidity $(\%)$, respectively, were $27^{\circ} \mathrm{C}$ and 59\% in August and $26.9^{\circ} \mathrm{C}$ and 61\% in September (INMET, 2013).

Melon field was sampled weekly from early August to late September by using passive and active collection methods, with a total of nine samples until the end of the survey. In the passive collection method, Pitfall and Moericke traps were installed on the $11^{\text {th }}$ day after planting (DAP), in the density of 20 traps of each type per hectare. The traps were distributed in parallel with the planting lines, from $20 \mathrm{~m}$ from the border, in the central lines of the crop. Pitfall and Moericke traps were spaced alternately $10 \mathrm{~m}$ apart to assess the diversity of predator insects. Pitfall traps consisted of plastic containers, measuring $12.5 \mathrm{~cm}$ in diameter and $8.5 \mathrm{~cm}$ high, were inserted into the ground in order to have their opening at the soil surface level. These traps were filled with 800 $\mathrm{ml}$ of an aqueous solution (neutral detergent (2\%), formaldehyde (5\%) and water (93\%)). Moericke traps were constituted by circular yellow plastic containers, $15.5 \mathrm{~cm}$ in diameter and $6.8 \mathrm{~cm}$ high, filled with $500 \mathrm{ml}$ of the same solution described previously. After sample collection, the solution was renewed. The active collection method was performed with a sweep net, with the sampling performed in random walking. At each collection, 20 points were sampled, with a minimum distance of ten meters from each other, where ten sweeps were made within a radius of one meter at each sampling point approximately. 
Collected insects were stored in plastic containers with $70 \%$ alcohol, labeled (place and collection date), and then transported to the laboratory. In the laboratory, the triage, counting and identification of predator insects at family level were carried out with support of a stereoscopic microscope and the taxonomic key of Triplehorn \& Johnson (2011).

For each taxonomic group collected, the relative abundance (RA) was determined by the following formula: AR $(\%)=\mathrm{n} / \mathrm{N} \times 100$, where, AR $(\%)=$ relative abundance; $\mathrm{n}=$ Total number of individuals in the taxon; $\mathrm{N}=$ Total number of individuals captured. The data were also interpreted using descriptive statistics, mainly for the most abundant taxa.

\section{Results and Discussion}

\subsection{Passive Collection Method}

A total of 5,704 insects were collected, distributed in six orders and 13 families (Table 1). Most of these insects (96.6\%) were recorded in the Pitfall traps. The order Dermaptera (earwigs), with a single family (Labiduridae), showed the highest relative abundance in the passive collection method, with $89.53 \%$ of the total number of insects caught, being most of them collected in Pitfall traps. Hymenoptera was the second group most captured (9.18\%), it also had the highest diversity of families, with four taxa: Formicidae, Vespidae, Mutillidae and Sphecidae. Formicidae was the most abundant with $6.91 \%$ of the captured specimens. The other orders (Diptera, Hemiptera, Coleoptera and Neuroptera) were less collected, with $1.32 \%$ of the insects caught (Table 1 ).

Table 1. Number $\left(\mathrm{N}^{\circ}\right)$ and relative abundance (RA\%) of predator insects families caught in passive collection method (Pitfall and Moericke traps) in melon crop in a semiarid region, from August to September 2012, municipality of Baraúna (RN), Brazil

\begin{tabular}{|c|c|c|c|c|c|c|c|}
\hline \multirow{2}{*}{ Orders } & \multirow{2}{*}{ Families } & \multicolumn{2}{|c|}{ Pitfall } & \multicolumn{2}{|c|}{ Moericke } & \multicolumn{2}{|c|}{ Total } \\
\hline & & $\mathrm{N}^{\mathrm{o}}$ & R.A. (\%) & $\mathrm{N}^{\mathrm{o}}$ & R.A. (\%) & $\mathrm{N}^{\mathrm{o}}$ & R.A. (\%) \\
\hline Dermaptera & Labiduridae & 5,087 & 89.18 & 20 & 0.35 & 5,107 & 89.53 \\
\hline \multirow{4}{*}{ Hymenoptera } & Formicidae & 346 & 6.07 & 48 & 0.84 & 394 & 6.91 \\
\hline & Vespidae & 18 & 0.32 & 16 & 0.28 & 34 & 0.60 \\
\hline & Mutillidae & 4 & 0.07 & 0 & - & 4 & 0.07 \\
\hline & Sphecidae & 0 & - & 91 & 1.60 & 91 & 1.60 \\
\hline \multirow{2}{*}{ Diptera } & Syrphidae & 18 & 0.32 & 3 & 0.05 & 21 & 0.37 \\
\hline & Dolichopodidae & 1 & 0.02 & 5 & 0.09 & 6 & 0.11 \\
\hline \multirow{2}{*}{ Hemiptera } & Reduviidae & 2 & 0.04 & 0 & - & 2 & 0.04 \\
\hline & Pyrrhocoridae & 1 & 0.02 & 1 & 0.02 & 2 & 0.04 \\
\hline \multirow{2}{*}{ Coleoptera } & Staphylinidae & 28 & 0.49 & 0 & - & 28 & 0.49 \\
\hline & Coccinellidae & 3 & 0.05 & 7 & 0.13 & 10 & 0.18 \\
\hline \multirow{2}{*}{ Neuroptera } & Chrysopidae & 0 & - & 4 & 0.07 & 4 & 0.07 \\
\hline & Myrmeleontidae & 0 & - & 1 & 0.02 & 1 & 0.02 \\
\hline General total & & 5,508 & & 196 & & 5,704 & \\
\hline
\end{tabular}

The Pitfall trap is characterized by estimating the species richness and relative abundance of various insect groups that preferentially exploit the soil surface (Gullan \& Cranston, 2017). This trap provided an expressive collection of earwigs, which shows a strong association of these insects with melon crop. The more abundance of earwigs could be explained by the habitat conditions. First, the studied area was located near maize crops (Zea mays L.), where these predators are usually found and second melon is grown during dry period of the year (between July and January), when there is less availability of shelter and food resources for natural enemies in the native vegetation of the semiarid region (Caatinga). It is very likely that earwigs search for more suitable environments, such as irrigated areas of melon crops. Studies in the guava crop (Psidium guajava L.) showed that the population peaks of these predators coincide with the harvest season, when there is greater food availability and higher temperatures which may increase the chances of survival in these environments (Galli, Seno, \& Cividanes, 2003). Recently, similar results were also recorded in watermelon crops, indicating that this family could be common in areas of cucurbit production in the semiarid region of Rio Grande do Norte (Costa et al., 2014b). 
On the other hand, it is important to emphasize that earwigs were more collected until flowering phase of melon (Figure 1). After this phase, influenced by applications of insecticides in the crop, the occurrence of the labidurids was reduced until the end of the crop cycle. The insecticides used in the melon crop might have affected the population of these predators in the field, causing either direct mortality or their escape from the insecticide-treated environment due to the reduction of prey (Aktar et al., 2009).

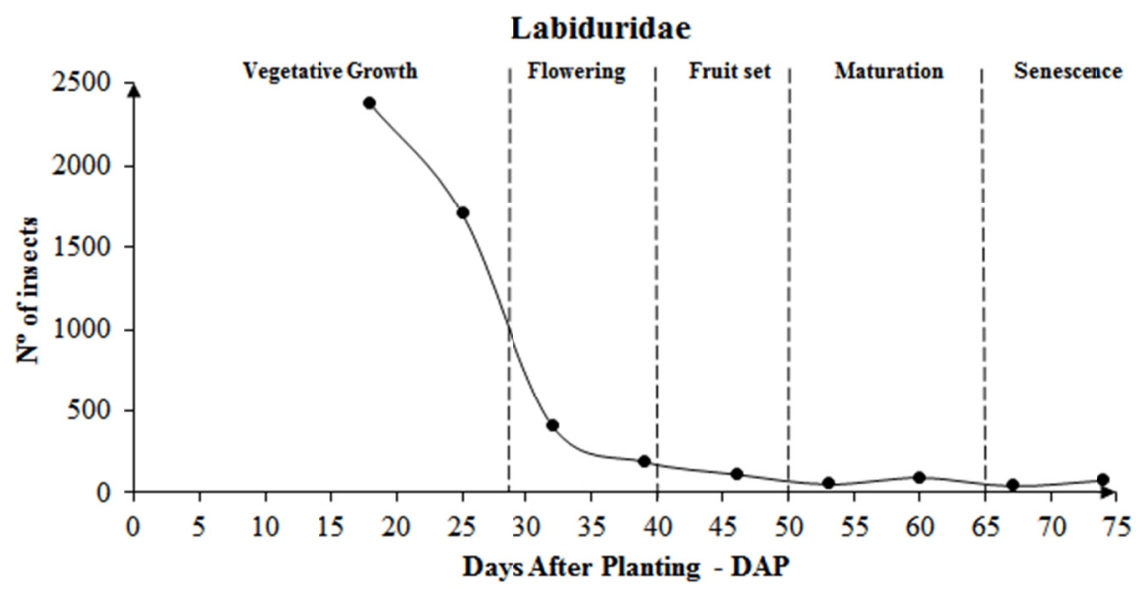

Figure 2. Number of insects collected of the Labiduridae family with Pitfall traps, in melon crop in a semiarid region, from August to September 2012, municipality of Baraúna (RN), Brazil

Due to its several ecological functions into the ecosystems, such as the predation of arthropod pests in the agrosystems (Abdulla, Rwegasira, Jensen, Mwatawala, \& Offenberg, 2015), it is worth mention the presence of Formicidae in the passive collections method. Some species of ants, especially of the genus Ectatomma, contribute to the natural biological control of other arthropods, however, in an agricultural environment studies are still necessary to determine the real impact of these ants on the suppression of pest populations (Delabie et al., 2007). Therefore, the occurrence of these insects seems to be important in the context of the trophic interactions within the melon crop and deserve more detailed studies.

\subsection{Active Collection Method}

A total of 107 predator insects, distributed in eight families, were collected with sweep nets (Table 2). The families Chrysopidae (Neuroptera) and Staphylinidae (Coleoptera) were the most abundant throughout the cycle of the melon crop with, approximately, $60.0 \%$ and $21.0 \%$ of the captured insects, respectively. The third family more abundant was Formicidae (Hymenoptera) with $10.28 \%$ of specimens collected. The families Pyrrhocoridae and Reduviidae (Hemiptera) had the fewest specimens captured in the melon crop, both totalizing 2.80\% (Table 2).

Table 2. Number $\left(\mathrm{N}^{\circ}\right)$ and relative abundance (RA\%) of predator insects families caught in active collection method (sweep net) in melon crop in a semiarid region, from August to September 2012, municipality of Baraúna (RN), Brazil

\begin{tabular}{|c|c|c|c|}
\hline \multirow{2}{*}{ Orders } & \multirow{2}{*}{ Families } & \multicolumn{2}{|c|}{ Sweep net } \\
\hline & & $\mathrm{N}^{\mathrm{o}}$ & RA (\%) \\
\hline Neuroptera & Chrysopidae & 64 & 59.81 \\
\hline Coleoptera & Staphylinidae & 22 & 20.56 \\
\hline \multirow{3}{*}{ Hymenoptera } & Formicidae & 11 & 10.28 \\
\hline & Vespidae & 1 & 0.93 \\
\hline & Mutillidae & 1 & 0.93 \\
\hline Diptera & Syrphidae & 5 & 4.67 \\
\hline \multirow{2}{*}{ Hemiptera } & Pyrrhocoridae & 2 & 1.87 \\
\hline & Reduviidae & 1 & 0.93 \\
\hline Total number of insects & & 107 & \\
\hline
\end{tabular}


The number of individuals captured in the active collection method was notably lower when compared with the passive collection. Labiduridae family was not captured by using sweep net, showing that earwigs have little preference to foraging on aerial part of the plant. However, the diversity of the families captured by sweep net was very similar to those obtained in passive collection method. Many types of insects, including predators, can be collected directly using the sweep net (Gullan \& Cranston, 2017). Possibly, for many of these natural enemies, plant foliage is a favorable environment for find prey, shelter or to find alternative sources of food (Coutinho, 2007).

Chrysopidae was the family with the highest number of specimens captured in the melon foliage, similar result was observed by Bezerra, Tavares, Macedo, Freitas, and Araujo (2010), demonstrating that chrysopids are common on melon crop in semiarid region of Rio Grande do Norte. These insects, especially larvae, are considered predators of many arthropod pests in agroecosystems (Pappas, Broufas, \& Koveos, 2011; Bezerra Tavares, Nogueira, Macedo, \& Araujo, 2012), including some melon pests such as whitefly (Araujo et al., 2008; Simmons \& Shaaban, 2011). During the sampling period, the greatest abundance of chrysopids occurred in the melon flowering phase. Possibly because this is the period in which the adults of this family usually search for alternative food, such as pollen and nectar in the flowers (Coutinho, 2007). The capture of chrysopids was reduced after the flowering phase (Figure 2), when the application of insecticides was intensified. Upon cessation of insecticides spraying on the crop, approximately 15 to 20 days before fruit harvest, the capture of the chrysopids increased gradually until the end of the crop cycle. This shows that the chrysopids visit the melon crop more frequently since the flowering season until the end of the crop cycle, especially if the insecticides applications do not interfere considerably in their populations.

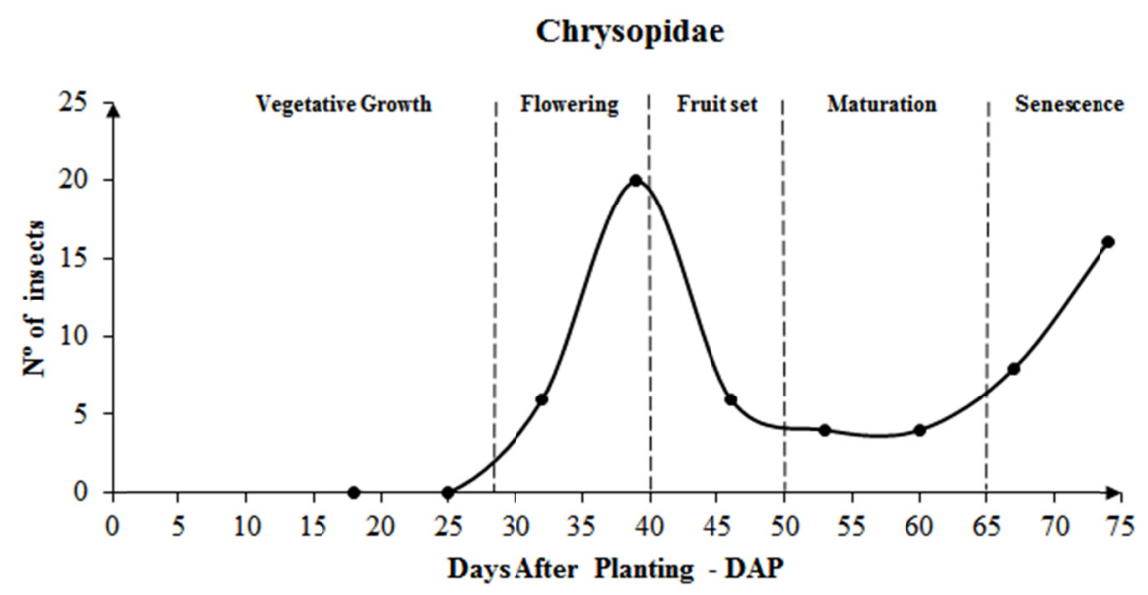

Figure 3. Number of insects collected of the Chrysopidae family with Sweep net, in melon crop in a semiarid region, from August to September 2012, municipality of Baraúna (RN), Brazil

Staphylinidae was the second most abundant family in the collection with sweep net. This family contains insects that are considered important predators in soils, where they act in the regulation of populations of agricultural pests (Martins, Cividanes, Barbosa, Araújo, \& Haddad, 2009). However, the capture of these insects in the melon foliage indicates that they visit the aerial parts of the plants in search for phytophagous insects.

Finally, the presence of insect families with predatory habits in the studied area indicates the presence of natural biological control in melon production areas in the semiarid region. However, it was observed that the use of insecticides can cause the reduction of these natural enemies. Thus, it is very important to use good agricultural practices such as pest monitoring, use of the level of economic damage and recognition/conservation of natural enemies. The information obtained shows that the insects of the families Labiduridae and Chrysopidae were the most abundant in the passive and active collections, respectively, demonstrating that the predators of these families possibly play an important role in the regulation of melon pests. Therefore, more detailed studies on these families should be carried out in order to know the potential of these predators for integrated pest management in the melon crop, in the semiarid region of Brazil. 


\section{References}

Abdulla, N. R., Rwegasira, G. M., Jensen, K.-M. V., Mwatawala, M. W., \& Offenberg, J. (2015). Effect of supplementary feeding of Oecophylla longinoda on their abundance and predatory activities against cashew insect pests. Biocontrol Science \& Technology, 25(11), 1333-1345. https://doi.org/10.1080/ 09583157.2015 .1057476

Aktar, M. W., Sengupta, D., \& Chowdhury, A. (2009). Impact of pesticides use in agriculture: Their benefits and hazards. Interdisciplinary Toxicology, 2(1), 1-12. https://doi.org/10.2478/v10102-009-0001-7

Araujo, E. L., Fernandes, D. R. R., Geremias, L. D., Filgueira, M. A., Guimarães, J. A., Mesquita, A. L. M., \& Braga Sobrinho, R. (2008). Controle biológico de pragas do meloeiro. In R. Braga Sobrinho, J. A. Guimarães, J. A. D. Freitas, \& D. Terão (Eds.), Produção integrada de melão (pp. 201-206). Fortaleza: Embrapa.

Bezerra, C. E. S., Tavares, P. K. A., Macedo, L. P. M., Freitas, S., \& Araujo, E. L. (2010). Green lacewings (Neuroptera: Chrysopidae) associated with melon crop in Mossoró, Rio Grande do Norte State, Brazil. Neotropical Entomology, 39(3), 454-455. https://doi.org/10.1590/S1519-566X2010000300024

Bezerra, C. E. S., Tavares, P. K. A., Nogueira, C. H. F., Macedo, L. P. M., \& Araujo, E. L. (2012). Biology and thermal requirements of Chrysoperla genanigra (Neuroptera: Chrysopidae) reared on Sitotroga cerealella (Lepidoptera: Gelechiidae) eggs. Biological Control, 60(2), 113-118. https://doi.org/10.1016/j.biocontrol. 2011.11.010

Costa, E. M., Araujo, E. L., Fernandes, D. R. R., Silva, P. A. F., \& Sales Júnior, R. (2016). Diversidade e métodos de amostragem de Hymenoptera na cultura da melancia no semiárido. Horticultura Brasileira, 34(2), 257-264. https://doi.org/10.1590/hb.v34i2.552

Costa, E. M., Araujo, E. L., Silva, F. E. L., Nogueira, C. H. F., \& Silva, P. A. F. (2014a). Diversidade de coleópteros em área cultivada com melancia no semiárido do Rio Grande do Norte. Agro@mbiente On-line, 8(2), 293-297. https://doi.org/10.18227/1982-8470ragro.v8i2.2058

Costa, E. M., Silva, P. A. F., Araujo, E. L., Santos, M. R. D., \& Sales Junior, R. (2014b). Fauna de Hemiptera, Orthoptera, Thysanoptera e Dermaptera capturada na cultura da melancia no semiárido do Rio Grande do Norte. Agropecuária Científica no Semi-árido, 10(3), 1-4.

Coutinho, C. (2007). Artrópodes auxiliares na agricultura. Coleção Agricultura com norte. Miradela, Portugal: Candeias Artes Gráficas.

Crowder, D. W., \& Jabbour, R. (2014). Relationships between biodiversity and biological control in agroecosystems: Current status and future challenges. Biological Control, 75, 8-17. https://doi.org/10.1016/ j.biocontrol.2013.10.010

Delabie, J. H. C., Alves, H. S. R., França, V. C., Martins, P. T. A., \& Nascimento, I. C. (2007). Biogeografia das formigas predadoras do gênero Ectatomma (Hymenoptera: Formicidae: Ectatomminae) no leste da Bahia e regiões vizinhas. Agrotrópica, 19, 13-20.

Galli, J. C., Seno, K. C. A., \& Cividanes, F. J. (2003). Flutuação populacional de Labidura sp. em Psidium guajava submetido a dois métodos de pulverização de fenthion. Manejo Integrado de Plagas y Agroecologia, 70, 45-49.

Gomes, G. B., Costa, E. M., Araujo, E. L., Sales Júnior, R., \& Silva, F. E. L. (2012). Levantamento preliminar da entomofauna associada à cultura da melancia no semiárido do Rio Grande do Norte. Agropecuária Científica no Semi-árido, 8(2), 12-15.

Gullan, P. J., \& Cranston, P. S. (2017). Insetos: Fundamentos da Entomologia. São Paulo: Editora Roca.

IBGE (Instituto Brasileiro de Geografia e Estatística). (2014). Produção Agrícola Municipal 2014: culturas temporárias e permanentes. Instituto Brasileiro de Geografia e Estatística, Ministério do Planejamento, Orçamento e Gestão. Brasil: Rio de Janeiro. Retrieved February 1, 2016, from http://biblioteca.ibge.gov.br/ visualizacao/periodicos/66/pam_2014_v41_br.pdf

INMET (Instituto Nacional de Meteorologia). (2016). BDMEP-Banco de dados meteorológicos para ensino e pesquisa. Retrieved February 25, 2016, from http:/www.inmet.gov.br/portal/\%20index.php?r=bdmep/ bdmep

Martins, I. C. F., Cividanes, F. J., Barbosa, J. C., Araújo, E. S., \& Haddad, G. Q. (2009). Análise de fauna e flutuação populacional de Carabidae e Staphylinidae (Coleoptera) em sistemas de plantio direto e 
convencional. Revista Brasileira de Entomologia, 53, 432-443. https://doi.org/10.1590/S0085-56262009 000300019

Pappas, M. L., Broufas, G. D., \& Koveos, D. S. (2011). Chrysopid predators and their role in biological control. Journal of Entomology, 8(3), 301-326. https://doi.org/10.3923/je.2011.301.326

Prado, D. E. (2003). As Caatingas da América do Sul. In I. R. Leal, M. Tabarelli, \& J. M. C. Silva (Eds.), Ecologia e conservação da Caatinga (pp. 3-74). Recife: Ed. Universitária da UFPE.

Simmons, A. M., \& Shaaban, A.-R. (2011). Populations of predators and parasitoids of Bemisia tabaci (Hemiptera: Aleyrodidade) after the application of eight biorational insecticides in vegetable crops. Pest Management Science, 67(8), 1023-1028. https://doi.org/10.1002/ps.2155

Triplehorn, C. A., \& Johnson, N. F. (2011). Estudo dos insetos. São Paulo: Editora Cengage Learning.

Vinutha, B., Kotikal, Y. K., Venkateshalu, V. M., Manjunath, G., \& Patil, S. (2017). Insect-pests composition and natural enemies association on oriental pickling melon, Cucumis melo var. conomon. Journal of Entomology and Zoology Studies, 5(5), 1838-1840.

\section{Copyrights}

Copyright for this article is retained by the author (s), with first publication rights granted to the journal.

This is an open-access article distributed under the terms and conditions of the Creative Commons Attribution license (http://creativecommons.org/licenses/by/4.0/). 